\title{
Iron-[S,S']-EDDS (FeEDDS) Chelate as an Iron Source for Horticultural Crop Production: Marigold Growth and Nutrition, Spectral Properties, and Photodegradation
}

\author{
Joseph P. Albano ${ }^{1}$ \\ USDA-ARS-U.S. Horticultural Research Laboratory, 2001 South Rock Road, \\ Fort Pierce, FL 34945
}

Additional index words. plant nutrition, FeEDTA, FeDTPA, photochemistry, complexone, ligand, water quality

Abstract. Aminopolycarboxylic acid (APCA) complexones, commonly referred to as ligands or chelating agents, like ethylenediaminetetraacetic acid (EDTA) and diethylenetriaminepentaacetic acid (DTPA), are commonly used in soluble fertilizers to supply copper $(\mathrm{Cu})$, iron $(\mathrm{Fe})$, manganese $(\mathrm{Mn})$, and/or zinc $(\mathrm{Zn})$ to plants. Offsite runoff and contamination of surface waters with these chelating agents is of increasing concern as a result of their reported ability to remobilize heavy metals in sediments and their low susceptibility to biodegradation. The APCA ethylenediaminedisuccinic acid (EDDS) is a structural isomer of EDTA with the $\left[S, S^{\prime}\right]$ stereoisomer of the complexone, a compound naturally produced by actinomycetes, and is biodegradable. Information on the use of $\left[S, S^{\prime}\right]$-EDDS as a chelating agent in formulating soluble fertilizers for the production of horticultural crops is limited. Therefore, a series of studies were conducted with the objectives of evaluating $\mathrm{Fe}\left[\mathrm{S}, \mathrm{S}^{\prime}\right]$-EDDS as an $\mathrm{Fe}$-chelate fertilizer agent in the production of marigold and [S,S']-EDDS (free ligand) and/or $\mathrm{Fe}\left[\mathrm{S}, \mathrm{S}^{\prime}\right]$-EDDS spectral properties and vulnerability to photodegrdation. Marigold grown in peat-based media were fertilized with complete nutrient solution containing $1 \mathrm{mg} \cdot \mathrm{L}^{-1} \mathrm{Fe}$ from FeEDDS, FeEDTA, or FeDTPA. There was no significant difference in foliar Fe or Mn between Fe-chelate treatments, averaging $140 \mu \mathrm{g} \cdot \mathrm{g}^{-1}$ and $88 \mu \mathrm{g} \cdot \mathrm{g}^{-1}$, respectively, nor were there significant differences in leaf dry weight $(2.30 \mathrm{~g})$ between Fe treatments. Spectra of [S, $\left.\mathrm{S}^{\prime}\right]-\mathrm{EDDS}$ and $\mathrm{Fe}\left[\mathrm{S}, \mathrm{S}^{\prime}\right]-$ EDDS produced from ferrous or ferric sources of Fe absorbed maximally in the 210 to 230 $\mathrm{nm}$ and 238 to $240-\mathrm{nm}$ range, respectively. The [S,S']-EDDS complexone used in the current study, a 30\% assay solution, had chromaphoric properties, appearing light yellow in color. When exposed to light, $\mathrm{Fe}\left[\mathrm{S}, \mathrm{S}^{\prime}\right]$-EDDS quickly degraded at a rate at least twice that of FeEDTA.

Aminopolycarboxylic acids like EDTA, diethylenetriaminetetraacetic acid (DTPA), and ethylenediamine-N, $\mathrm{N}^{\prime}$-bis(2-hydroxyphenylacetic) acid (EDDHA) are synthetically produced organic compounds known as complexones but commonly referred to in the trade as ligands or chelating agents. These com-

Received for publication 31 Mar. 2011. Accepted for publication 17 May 2011.

The USDA-ARS Floriculture and Nursery Research Initiative is recognized for partial support of this work.

I thank Chris Lasser, Ryan Hamm, and Marcus Martinez for technical assistance and Greg McCollum and Robert Shatters for critical reading and improving the text.

Contribution to USDA-ARS Research Project 6618-13000-003-00D “Integrated Horticultural Production Systems for Water Quality Protection and Water Conservation."

I dedicate this article to the memory of Donald "Andy" Hamm (1967-2008), a good technician and a great friend. You are sorely missed.

${ }^{1}$ To whom reprint requests should be addressed; e-mail joseph.albano@ars.usda.gov. to degrade water quality by mobilizing metals, its use in Europe is being phased out and replaced with EDDS (Metsärinne et al., 2001).

A structural isomer of EDTA, EDDS has two chiral centers and three stereoisomer configurations: $\left[S, S^{\prime}\right],\left[R, R^{\prime}\right]$, and $\left[S, R^{\prime} / R, S^{\prime}\right]$. Unlike EDTA, a synthetic compound, the [S, $\left.\mathrm{S}^{\prime}\right]$-EDDS stereoisomer is produced by actiomycetes (Egli, 2001; Nörtemann, 2005). The naturally produced $\left[\mathrm{S}, \mathrm{S}^{\prime}\right]$ stereoisomer is readily biodegradable, whereas the $\left[R, R^{\prime}\right]$ and $\left[S, R^{\prime} / R, S^{\prime}\right]$ stereoisomers of EDDS are not or only partially biodegradable, respectively (Schowanek et al., 1997; Tandy et al., 2006). The biodegradability of EDDS is of importance because its environmental signature, relative to EDTA and other synthetically produced APCA complexones, is short in duration, broken down microbially or by photooxidation (i.e., photodegradation) when complexed with Fe. Iron chelates of EDTA and DTPA are also vulnerable to photodegradation.

Photodegradation of FeDTPA or FeEDTA occurs in fertilizers, resulting in the loss of soluble (i.e., plant available) Fe. Photodegradation of FeEDTA [maximum absorbance $\left.\left({ }^{\lambda} \max \right)=258 \mathrm{~nm}\right]$ and FeDTPA $\left({ }^{\lambda} \max =260\right.$ $\mathrm{nm})$ were found to occur in fertilizers when exposed to spectral energy primarily in the ultraviolet (UV) A and UVB portions of the spectrum (Albano and Miller, 2001a, 2003). Use of photodegraded fertilizers in the production of horticultural crops was found to have a negative impact on plant growth and physiology. Marigold grown hydroponically (Albano and Miller, 2001b), or tomato grown in peat-based media (Albano and Miller, 2003) supplied with photodegraded Fe-chelatecontaining fertilizer solution, expressed root physiology or nutrition associated with $\mathrm{Fe}$ deficiency induced Strategy I Fe efficiency. These plants had enhanced root ferric reductase activity (marigold) and higher levels of foliar $\mathrm{Mn}$ (marigold and tomato) than in control treatments (i.e., Fe-chelate containing fertilizer that was not irradiated) indicating that plants were responding to the loss of soluble Fe as a result of photodegradation of Fe-chelates (Albano and Miller, 2001b, 2003).

Iron-EDDS has been reported to degrade when exposed to UV radiation (Gorokhovatskaya et al., 1990; Metsärinne et al., 2001). These studies, however, were conducted on mixed stereoisomer EDDS solutions. Information could not be found on the absorbance spectra or vulnerability to photodegradation of pure $\left[\mathrm{S}, \mathrm{S}^{\prime}\right]$-EDDS as a free ligand or Fe-complexed compound. Such information is important for developing formulations and handling protocols for [S, $\left.\mathrm{S}^{\prime}\right]$-EDDS-containing fertilizers because this stereoisomer is biodegradable and will most likely be used as a replacement for nonbiodegradable APCAs (e.g., EDTA, DTPA, EDDHA) in fertilizers. Therefore, the objectives of this study were: 1) to determine the performance of $\mathrm{Fe}\left[\mathrm{S}, \mathrm{S}^{\prime}\right] \mathrm{EDDS}$ as a fertilizer agent for the production of marigold; 2) to determine the absorbance spectra for freeligand and $\mathrm{Fe}$-chelated [S, $\left.\mathrm{S}^{\prime}\right]$-EDDS; and 3) to assess free-ligand and Fe-chelated [S, $\left.\mathrm{S}^{\prime}\right]$ EDDS vulnerability to photodegradation. 


\section{Materials and Methods}

Growing conditions. Marigold (Tagetes erecta, 'First Lady') seeds were sown in sixcell grow-packs $\left(40 \mathrm{~cm}^{3}\right.$ per cell) containing a moistened soilless peat-based medium (Fafard 4P; Conrad Fafard, Inc., Agawam, MA). Seeds germinated 2 to $3 \mathrm{~d}$ after sowing (DAS). Treatments were initiated on 12 DAS when the first true leaf pairs (TLP) were fully expanded and subsequently applied on 19, $24,26,28,30,32$, and 34 DAS. Tissue samples were collected 35 DAS when TLP 5 was fully expanded. The experiment used a completely randomized design with three treatments (FeEDTA, FeEDDS, and FeDTPA) and four replications per treatment with a replication consisting of six plants. The study was conducted in a double-walled polycarbonate-glazed greenhouse located in Fort Pierce, FL (lat. $27.41^{\circ} \mathrm{N}$, long. $80.35^{\circ} \mathrm{W}$ ), 13 July (sowing) to 17 Aug. (harvest) 2006. Growing temperatures over the course of the experiment were $31 / 27{ }^{\circ} \mathrm{C}$ day/night, respectively. Treatment application $(300 \mathrm{~mL})$ was evenly distributed among cells of a grow-pack, and leaching fractions over the course of the study averaged $40 \% \pm 5 \%$

$\mathrm{Fe}\left[S, S^{\prime}\right]-E D D S$ preparation. Equal molar concentrations of $\mathrm{Fe}$ from ferrous [Fe(II)] $\mathrm{FeSO}_{4} \cdot 7 \mathrm{H}_{2} \mathrm{O}$ (Fisher Scientific, Fair Lawn, $\mathrm{NJ}$ ) or ferric $[\mathrm{Fe}(\mathrm{III})] \mathrm{Fe}_{2}\left(\mathrm{SO}_{4}\right)_{3} \cdot \mathrm{H}_{2} \mathrm{O}$ (SigmaAldrich, Inc., St. Louis, MO) and [S, $\left.\mathrm{S}^{\prime}\right]$-EDDS trisodium salt (Fluka Analytical, Steinheim, Germany) solutions were placed on a stir plate and allowed to react for a minimum of $12 \mathrm{~h}$ in the dark before use. Formation of FeEDDS was confirmed by direct infusion liquid chromatography-mass spectroscopy (Thermo Finnigan LCQ-DECA; ThermoQuest, San Jose, CA) (data not shown). Iron concentration, 17.9 $\mathrm{mmol} \cdot \mathrm{L}^{-1}\left(1000 \mathrm{mg} \cdot \mathrm{L}^{-1}\right) \mathrm{Fe}$ from FeEDDS was confirmed by inductively coupled plasmaoptical emission spectrometry (ICP-OES) (IRIS 1000 HR Duo; ThermoElemental, Franklin, MA; or iCAP 6500; Thermo Scientific, Waltham, MA) (data not shown). IronEDDS prepared from $\mathrm{Fe}(\mathrm{II})$ sulfate $\left(\mathrm{SO}_{4}\right)$ was used in the marigold production study, whereas FeEDDS prepared from $\mathrm{Fe}(\mathrm{II}) \mathrm{SO}_{4}$ and $\mathrm{Fe}(\mathrm{III}) \mathrm{SO}_{4}$ were used in spectral and photodegradation studies. All solutions were prepared with distilled-deionized water (DDI).

Nutrient solution treatments. A base nutrient solution (BNS) was laboratory prepared and contained the following concentrations $\left(\mathrm{mg} \cdot \mathrm{L}^{-1}\right)$ of essential plant nutrients: 200 nitrogen, 44 phosphorus, 164 potassium, 113 calcium, 49 magnesium, 64 sulfur, $1 \mathrm{Fe}, 0.5$ boron, $0.5 \mathrm{Mn}, 0.05 \mathrm{Zn}, 0.02 \mathrm{Cu}$, and 0.05 molybdenum. Source reagents for preparing BNS were: $\mathrm{KNO}_{3}, \mathrm{KH}_{2} \mathrm{PO}_{4}, \mathrm{MgSO}_{4}, \mathrm{Ca}\left(\mathrm{NO}_{3}\right)_{2}$, $\mathrm{NH}_{4} \mathrm{NO}_{3},\left(\mathrm{NH}_{4}\right)_{2} \mathrm{H}_{2} \mathrm{PO}_{4}, \mathrm{CaHPO}_{4}, \mathrm{H}_{3} \mathrm{BO}_{3}$, and $\mathrm{H}_{2} \mathrm{MoO}_{4}$. Treatments consisted of FeEDDS, FeEDTA (Sigma-Aldrich), or FeDTPA (SigmaAldrich) added to BNS at $1 \mathrm{mg} \cdot \mathrm{L}^{-1} \mathrm{Fe}$ final concentration. Manganese, $\mathrm{Cu}$, and $\mathrm{Zn}$ were supplied as EDTA chelates. The BNS and Fechelates were prepared with DDI water. Treatment solutions were adjusted to $\mathrm{pH} 5.8$ with $\mathrm{HCl}$ or $\mathrm{KOH}$ ( $0.1 \mathrm{~N}$ solutions) before applica- tion. This treatment solution $\mathrm{pH}$ ensured that EDDS, EDTA, and DTPA remained as Fe chelates, eliminating the possibility for lower chelate affinity metals, $\mathrm{Cu}, \mathrm{Mn}$, or $\mathrm{Zn}$, from displacing Fe.

Leaf sampling and analysis. Primary and axial leaf tissue was collected 35 DAS and washed in sequence for $\approx 10$ to $15 \mathrm{~s}$ in each of the following solutions: DDI, $0.1 \mathrm{~N} \mathrm{HCl} /$ $0.01 \%$ detergent (Tween-80), and $3 \times$ DDI rinses. Washed leaf tissue was dried in a forced-air oven at $80^{\circ} \mathrm{C}$, weighed, and milled to pass a 20 -mesh screen. Milled plant tissue was digested using a closed-vessel microwave-assisted procedure according to U.S. EPA Method 3052 (1997). Briefly, $500 \mathrm{mg}$ of leaf tissue was combined with $10 \mathrm{~mL}$ concentrated $\mathrm{HNO}_{3}$ (trace metal grade) in a Teflon digestion vessel and processed in a microwave digestion oven (MARS Express; CEM Corp., Matthews, NC). Digestion conditions (internal) were $170{ }^{\circ} \mathrm{C}$ and $2068 \mathrm{kPa}$ (300 psi) held for 10 min after a 15 -min ramp to these conditions. Digestates were transferred quantitatively to $100-\mathrm{mL}$ volumetric flasks, filtered through Whatman 541 (Whatman Int., Kent, U.K.), and analyzed for Fe and $\mathrm{Mn}$ by ICP-OES (IRIS 1000 HR DUO) according to U.S. EPA Method 6010B (1997).

Table 1. Leaf Fe, Mn, and dry weight (DW) for marigold grown in peat-based media in six-celled grow packs supplied with a complete fertilizer solution $\left(200 \mathrm{mg} \cdot \mathrm{L}^{-1} \mathrm{~N}\right)$ containing FeEDDS, FeEDTA, or FeDTPA $\left(1 \mathrm{mg} \cdot \mathrm{L}^{-1} \mathrm{Fe}\right){ }^{\mathrm{z}}$

\begin{tabular}{lccc}
\hline Fe Chelate Source & $\mathrm{Fe}\left(\mu \mathrm{g} \cdot \mathrm{g}^{-1}\right)$ & $\mathrm{Mn}\left(\mu \mathrm{g} \cdot \mathrm{g}^{-1}\right)$ & $\mathrm{DW}(\mathrm{g})$ \\
\hline FeEDDS & $150.35 \pm 9.75$ & $95.50 \pm 9.09$ & $2.42 \pm 0.40$ \\
FeEDTA & $133.13 \pm 5.85$ & $85.21 \pm 5.90$ & $2.27 \pm 0.50$ \\
FeDTPA & $137.68 \pm 7.43$ & $82.95 \pm 7.43$ & $2.22 \pm 0.29$ \\
Significance $(P \leq 0.05)$ & 0.3203 & 0.4998 & 0.7761 \\
\hline
\end{tabular}

${ }^{2}$ Values are the mean of four replications.

$\mathrm{Fe}=$ iron; $\mathrm{Mn}=$ manganese $; \mathrm{EDDS}=$ ethylenediaminedisuccinic acid EDTA $=$ ethylenediaminetetraacetic acid; DTPA = diethylenetriaminepentaacetic acid.

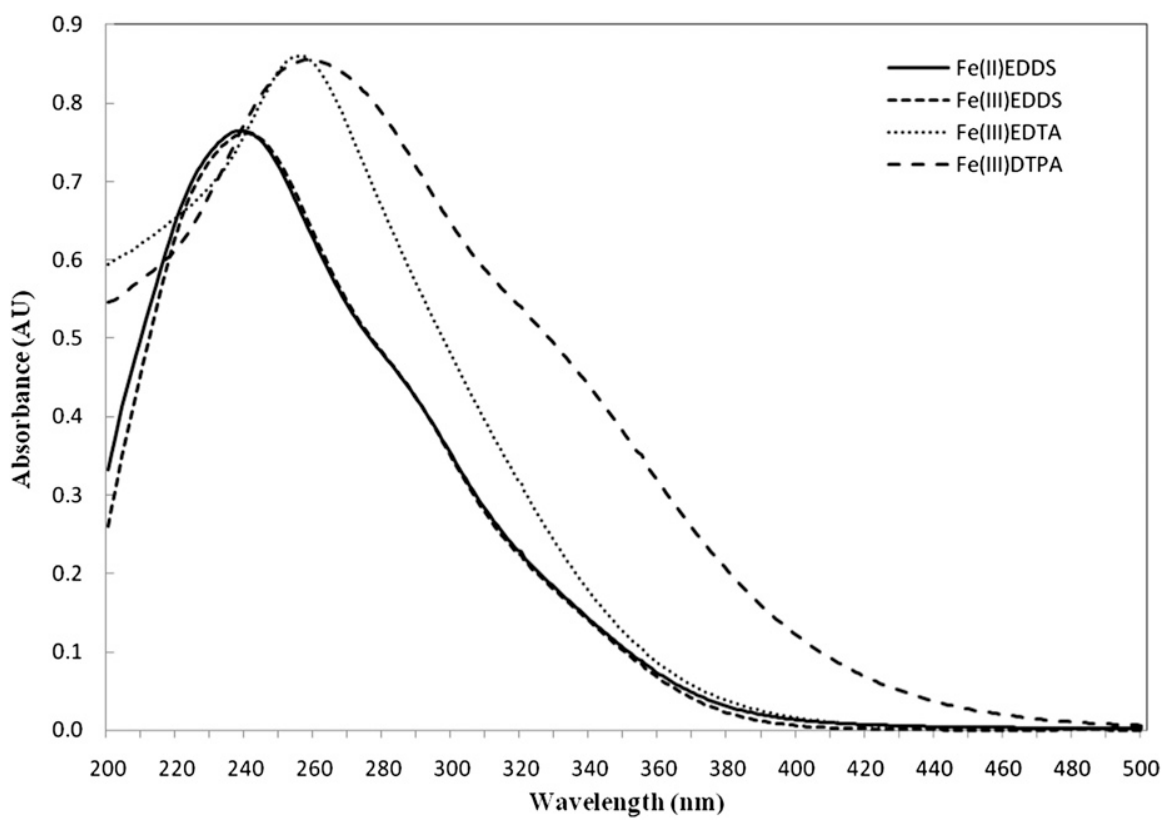

Fig. 1. Absorbance spectra of $35.8 \mu \mathrm{mol} \cdot \mathrm{L}^{-1} \mathrm{Fe}-\left[\mathrm{S}, \mathrm{S}^{\prime}\right]$-EDDS produced ferrous sulfate (-) or ferric sulfate (---) solutions blanked against $35.8 \mu \mathrm{mol} \cdot \mathrm{L}^{-1}$ free $\left[\mathrm{S}, \mathrm{S}^{\prime}\right]$-EDDS, $35.8 \mu \mathrm{mol} \cdot \mathrm{L}^{-1} \mathrm{Fe}(\mathrm{III}) \mathrm{EDTA}(\cdots)$, and Fe(III)DTPA (- - -) solutions blanked against distilled-deionized water. Scans are the mean of three discrete samples. 
FeDTPA, and free DTPA ligand. The mean of three discrete samples was used for analysis and studies were repeated.

FeEDDS photodegradation. Solutions (1 L) of $\mathrm{Fe}$ (III)EDDS, Fe(II)EDDS, free EDDS ligand, or FeEDTA $\left(179 \mu \mathrm{mol} \cdot \mathrm{L}^{-1}\right)$ were contained in translucent 1-L low-density polyethylene (LDPE) bottles (Nalgene Co., Rochester, NY). Containers made of PE were selected because this material transmits nearly $100 \%$ ultraviolet radiation (200 to $400 \mathrm{~nm}$ ) (Yang and Ranby, 1996). Treatment solutions were irradiated with $2772 \mu \mathrm{mol} \cdot \mathrm{m}^{-2} \cdot \mathrm{s}^{-1}$ portioned as follows: $862 \pm 32 \mu \mathrm{mol} \cdot \mathrm{m}^{-2} \cdot \mathrm{s}^{-1}[250$ to $\left.400 \mathrm{~nm}\left(188 \pm 15 \mathrm{~W} \cdot \mathrm{m}^{-2}\right)\right]$ and $1910 \pm 190$ $\mu \mathrm{mol} \cdot \mathrm{m}^{-2} \cdot \mathrm{s}^{-1}$ (400 to $700 \mathrm{~nm}$ ) measured at the external container surface using an Apogee Instruments, Model UVM, ultraviolet meter (Logan, UT) and a LI-COR, Model LI-250 light meter paired with a LI-COR quantum sensor (Lincoln, NE), respectively. Containers were placed on their sides for irradiation and control solutions were nonirradiated by covering with aluminum foil. Irradiance source was two 1000-W metal halide lamps (Multi-Vapor R1000 MVR1000/U; GE Co., Fairfield, CT) with a distance between the container surface and lamp at $25 \mathrm{~cm}$. The lamp reflector box (2) angled out to a base dimension of $52 \times 52 \mathrm{~cm}$. Solution temperature during irradiation was $32.6 \pm 1.1^{\circ} \mathrm{C}$. At 0,6 , and $12 \mathrm{~h}$ irradiation, $100-\mathrm{mL}$ aliquots of sample solution were collected; $50 \mathrm{~mL}$ of each aliquot was centrifuged at $2000 g_{\mathrm{n}}$ for $1 \mathrm{~h}$ in a Sorvall H1000B swinging-bucket rotor (DuPont Instruments, Wilmington, DE) at room temperature. The supernatant was reserved and absorbance determined at 238 and $258 \mathrm{~nm}$ on a spectrophotometer (previously described) for FeEDDS and FeEDTA, respectively. Blanks for FeEDDS samples were corresponding, in time, 0,6 , and $12 \mathrm{~h}$ irradiated free EDDS ligand samples (i.e., blanks that had received the same exposure) and DDI for FeEDTA. The supernatant for FeEDDS and FeEDTA samples was also analyzed for Fe by ICP-OES (iCAP 6500). There were four replications per treatment and the study was repeated.

Statistics. Data in the marigold production study, leaf Fe, Mn, and dry weight (DW), were analyzed by analysis of variance to determine the main effect of Fe-chelate treatment. Calculations were performed by the general linear model procedure of SAS (SAS Institute, Cary, NC). For the spectral property scans and photodegradation work, primary and repeated photochemistry reactions were not different; therefore, means from the primary studies are presented. For spectral property studies, data were generated from the mean of three discrete samples per treatment. For the photodegradation work, data were generated from the mean of four replications per treatment.

\section{Results and Discussion}

Plant nutrition. There were no visual differences in plant color, size, or shape between treatments. Means were not separated for $\mathrm{Fe}, \mathrm{Mn}$, or leaf DW because no main effect generated a $P \leq 0.05$ (Table 1). Mean foliar levels of Fe and Mn were 140 and $88 \mu \mathrm{g} \cdot \mathrm{g}^{-1}$, respectively. These levels are considered sufficient for normal bedding plant growth (Vetanovetz, 1996). As a mean of Fe treatment, the foliar Fe:Mn ratio $(1.7 \mathrm{Fe}: 1 \mathrm{Mn})$ was close to that supplied (2 Fe:1 Mn). Based on these data, FeEDDS is a suitable Fe source for producing marigold.

Manganese in the current study was supplied as an EDTA chelate as was $\mathrm{Cu}$ and $\mathrm{Zn}$. The suitability of EDDS as a chelant for $\mathrm{Cu}, \mathrm{Mn}$, or $\mathrm{Zn}$ for fertilizers used in the pro- duction of horticultural crops is unknown but appears to be influenced by $\mathrm{pH}$. According to Orama et al. (2002), EDDS chelation pH ranges for $\mathrm{Cu}$ (II), $\mathrm{Fe}(\mathrm{III}), \mathrm{Mn}(\mathrm{II})$, and $\mathrm{Zn}$ (II) are 3 to 12,3 to 9,8 to 12 , and 5 to 12 , respectively. For $\mathrm{Cu}, \mathrm{Fe}$, and $\mathrm{Zn}$, the reported $\mathrm{pH}$ chlelation ranges for EDDS fall within the generally recommended $\mathrm{pH}$ range for growing most greenhouse bedding crops, 5.4 to 6.8 (Nelson, 1999). For Mn, however, the reported chelation $\mathrm{pH}$ range falls outside of that recommended for bedding plant production. This is something that requires further

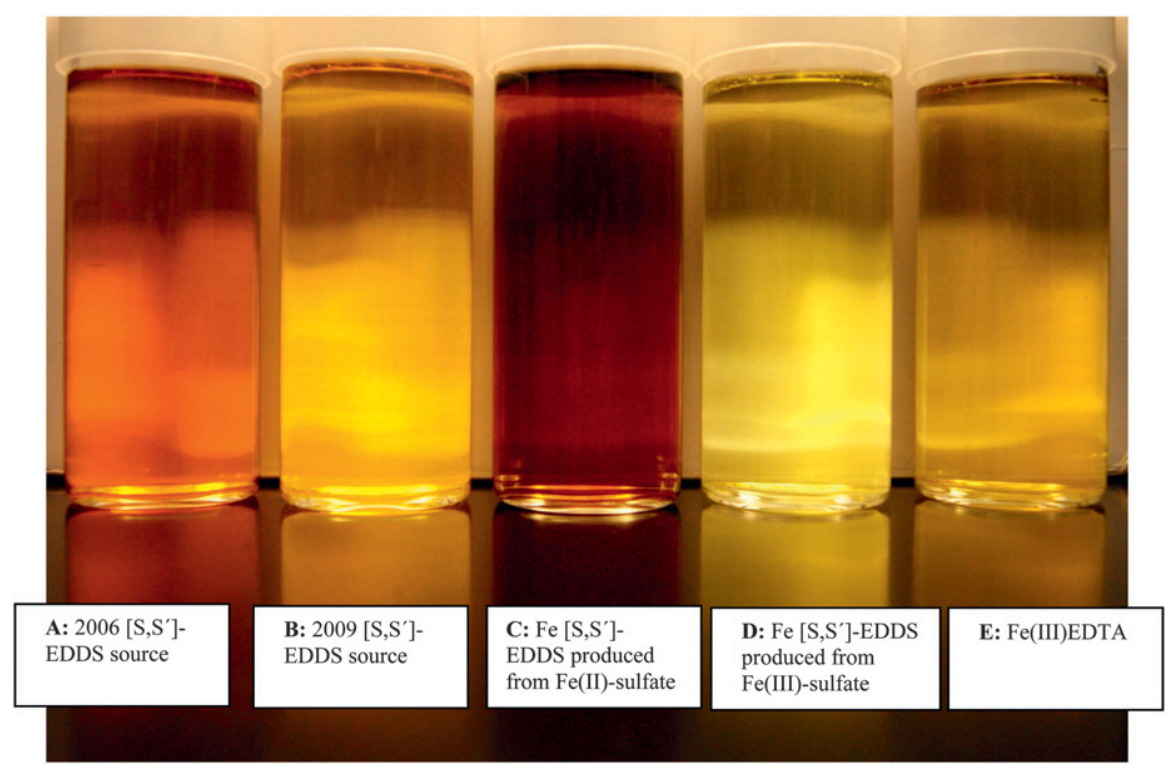

Fig. 2. Visual color differences between solutions $\left(17.9 \mathrm{mmol} \cdot \mathrm{L}^{-1}\right)$ of a 2006 (A) and 2009 (B) source of [S, $\left.\mathrm{S}^{\prime}\right]$-EDDS, Fe-[S,S']-EDDS produced ferrous sulfate $(\mathbf{C})$ or ferric sulfate $(\mathbf{D})$ using the 2009 [S, $\left.\mathrm{S}^{\prime}\right]$ EDDS source, and FeEDTA (E).

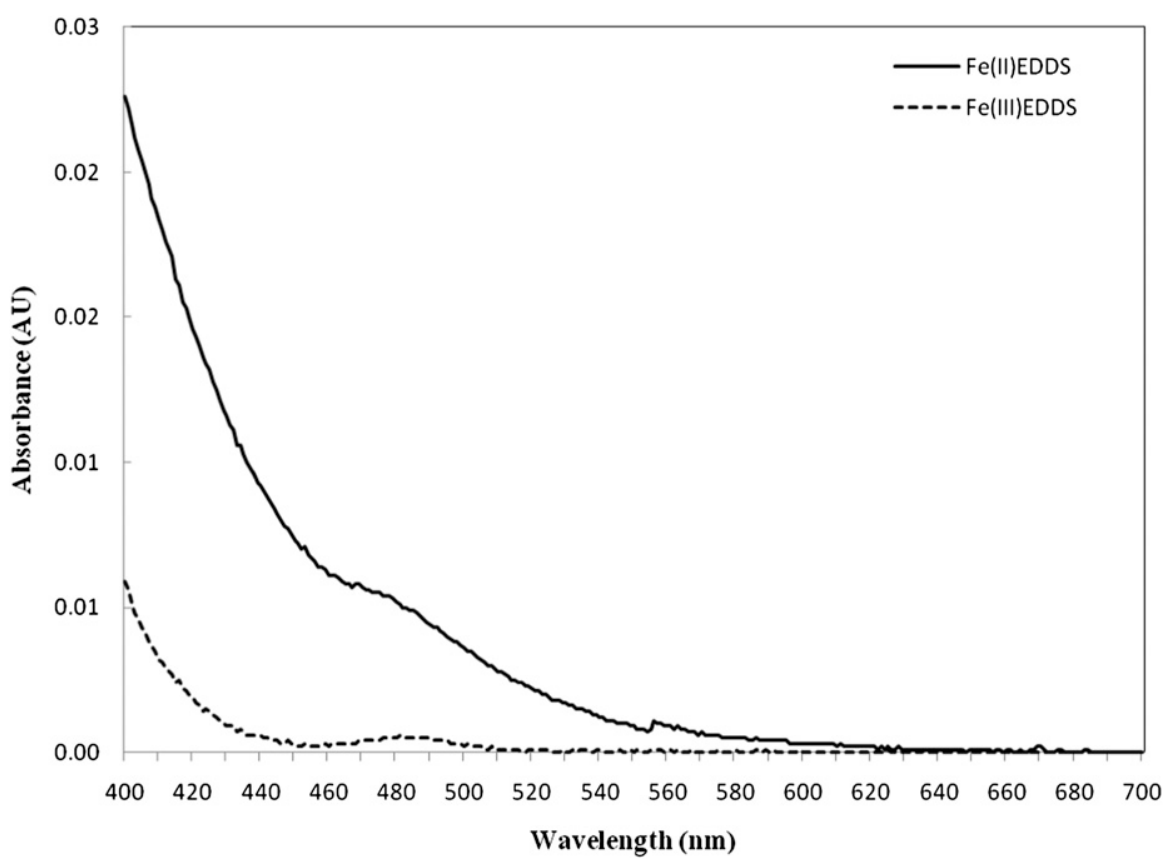

Fig. 3. Absorbance spectra of Fe-[S, $\left.\mathrm{S}^{\prime}\right]$-EDDS $\left(35.8 \mu \mathrm{mol} \cdot \mathrm{L}^{-1}\right)$ produced ferrous sulfate $(-)$ or ferric sulfate (- -) in the photosynthetically active radiation region of the spectrum blanked against 35.8 $\mu \mathrm{mol} \cdot \mathrm{L}^{-1}\left[\mathrm{~S}, \mathrm{~S}^{\prime}\right]$-EDDS (free ligand). Scans are the mean of three discrete samples. 
investigation. Regardless, EDDS does share with EDTA and DTPA the same metal binding affinity profile, $\mathrm{Fe}>\mathrm{Cu}>\mathrm{Zn}>\mathrm{Mn}$ (BucheliWitschel and Egli, 2001; Jones and Williams, 2001).

Spectral properties of FeEDDS and EDDS. Iron-EDDS solutions were initially scanned using DDI water and EDDS as blanks. As a result of EDDS chromaphoric properties and where FeEDDS absorbs in the UV spectrum, it was difficult to discern peak absorbance of FeEDDS from absorbance of free EDDS ligand when DDI water was used as blank. Therefore, equal molar concentrations of EDDS were used as a blank for FeEDDS data reported here. Freshly prepared (nonirradiated) solutions of $\mathrm{Fe}$ (II)EDDS and Fe(III)EDDS $\left(89.5 \mu \mathrm{mol} \cdot \mathrm{L}^{-1}\right)$ absorbed strongly in the UV regions of the spectrum, peaking in the 238 to $240-\mathrm{nm}$ range with ${ }^{\lambda} \max$ at $238 \mathrm{~nm}$ used for determining AU (Fig. 1). Iron-EDDS sources were reddish and yellow color in appearance for $\mathrm{Fe}(\mathrm{II})$ and $\mathrm{Fe}$ (III) forms of the chelate, respectively (Fig. 2). Absorbance of spectral energy ( $\geq 0.01 \mathrm{AU}$ ) for solutions of $\mathrm{Fe}(\mathrm{II}) \mathrm{EDDS}$ and Fe(III)EDDS began at 435 and $402 \mathrm{~nm}$, respectively. The SAU for Fe(II)EDDS (238 to $435 \mathrm{~nm}$ ) and Fe(III)EDDS (238 to $402 \mathrm{~nm}$ ) were 45.56 and 48.35 , respectively. In the photosynthetically active radiation region of the spectrum (400 to 700 $\mathrm{nm}), \mathrm{Fe}(\mathrm{II}) \mathrm{EDDS}$ had greater absorbance (0.71 SAU) than Fe(III)EEDS (0.12 SAU), possibly contributing to the observed color differences between these $\mathrm{Fe}$ forms of the EDDS chelate complex (Fig. 3). These solutions also varied significantly in $\mathrm{pH}$ with Fe(II)EDDS and Fe(III)EDDS being basic ( $\mathrm{pH} 7.8$ ) and acidic ( $\mathrm{pH} 3.5)$, respectively.

The free EDDS ligand $\left(17.9 \mathrm{mmol} \cdot \mathrm{L}^{-1}\right)$ had absorbance in the visible spectrum (400 to $550 \mathrm{~nm}$ ) and therefore had color (Figs. 2 and 4) but absorbed maximally in the 210 to 230-nm range (Fig. 5), which was confirmed with two separate sources of the complexone (Figs. 2, 4, and 5). This is consistent with work by Gorokhovatskaya et al. (1990) in which free EDDS ligand $\left(100 \mu \mathrm{mol} \cdot \mathrm{L}^{-1}\right)$ was reported to maximally absorb at $220 \mathrm{~nm}$. The $\mathrm{pH}$ of EDDS solutions was 9.5. Personal communication with the manufacturer of EDDS used in the current studies confirmed the chromophoric properties of the complexone (i.e., the light yellow color that was observed in fresh product). The 2006 EDDS source's color shifted from light yellow to reddish in color over time. Unlike the 2009 EDDS source, which was protected from light from time of acquisition, the 2006 source was exposed to ambient fluorescent lighting in the laboratory. Residual Fe levels (contaminant) of laboratory-prepared $17.9 \mathrm{mmol} \cdot \mathrm{L}^{-1}$ EDDS stock solution, determined by ICP-OES (iCAP 6500 ), were low at $0.059 \pm 0.01 \mathrm{mg} \cdot \mathrm{L}^{-1}$ but possibly sufficient enough to contribute to the complexones observed yellow to reddish color. Regardless, the effect of irradiation on EDDS is discussed in the next section on photodegradation. The chromophoric character of EDDS is significantly different from that of free EDTA or DTPA ligands, which are

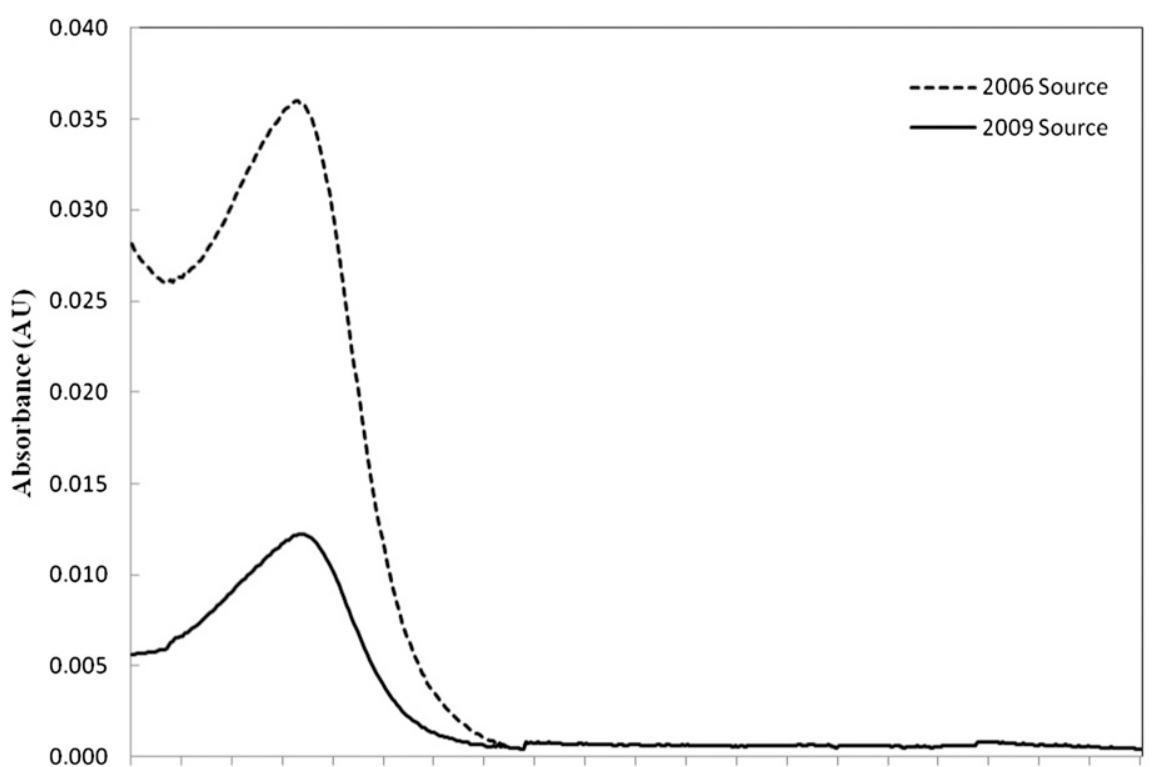

400420440460480500520540560580600620640660680700720740760780800 Wavelength (nm)

Fig. 4. Absorbance spectra (400 to $800 \mathrm{~nm}$ ) of a $2006(--)$ and $2009(-)$ [S,S']-EDDS $\left(17.9 \mathrm{mmol} \cdot \mathrm{L}^{-1}\right)$ sources blanked against distilled-deionized water. Scans are the mean of three discrete samples.

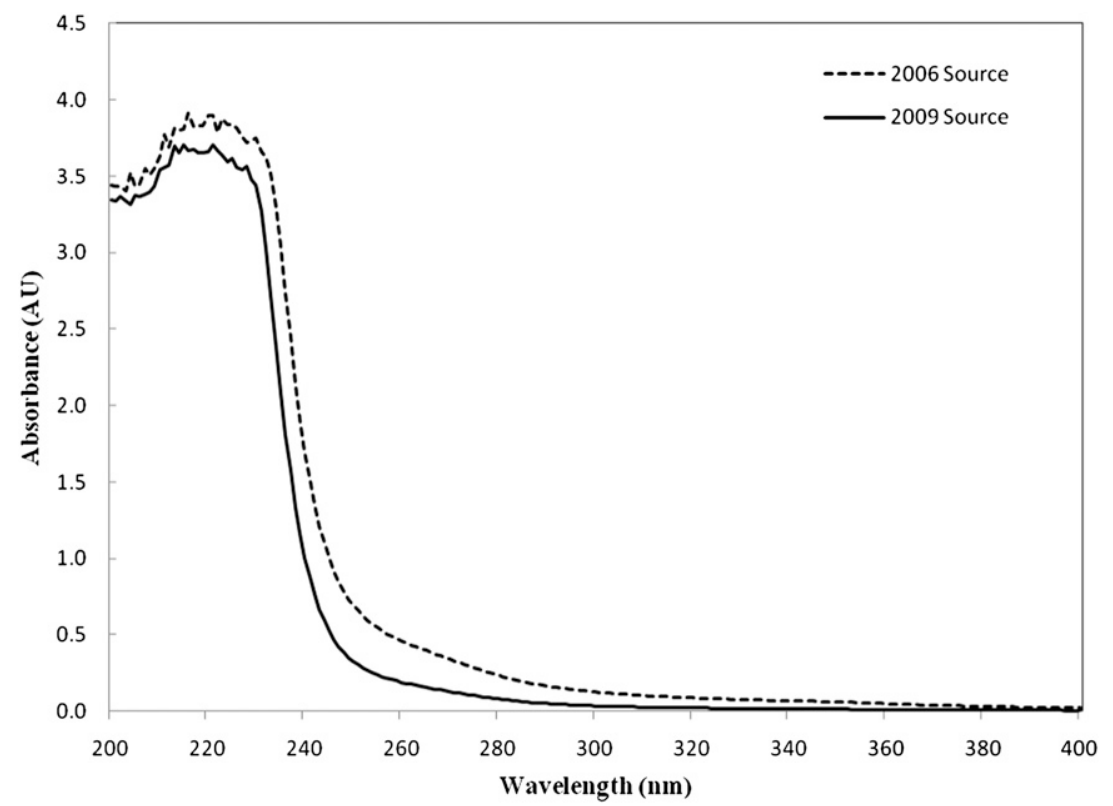

Fig. 5. Absorbance spectra (200 to $400 \mathrm{~nm}$ ) of a $2006(--)$ and $2009(-)$ [S,S']-EDDS (17.9 mmol. $\left.\mathrm{L}^{-1}\right)$ sources blanked against distilled-deionized water. Scans are the mean of three discrete samples.

colorless solutions. Spectral scans of free EDTA and DTPA ligands $\left(35.8 \mu \mathrm{mol} \cdot \mathrm{L}^{-1}\right)$ began to absorb at $258 \mathrm{~nm}$ with absorbance increasing sharply to $200 \mathrm{~nm}$ (data not shown).

Photodegradation of $\mathrm{Fe}-\left[S, S^{\prime}\right]-E D D S$. There was no difference between Fe(II)EDDS and $\mathrm{Fe}(\mathrm{III}) \mathrm{EDDS}\left(179 \mu \mathrm{mol} \cdot \mathrm{L}^{-1}\right)$ response to irradiation; therefore, the term FeEDDS will represent both $\mathrm{Fe}$ forms. Iron-EDDS degraded when exposed to light and it degraded more rapidly when illuminated than FeEDTA (Fig. 6A). Complete degradation of FeEDDS and FeEDTA occurred within 6 and 12 h, respectively, for $179 \mu \mathrm{mol} \cdot \mathrm{L}^{-1}$ solutions of the $\mathrm{Fe}$ - chelates. The loss in absorbance at 238 and 258 $\mathrm{nm}$ for FeEDDS and FeEDTA, respectively, corresponded with the loss in soluble Fe (Fig. $6 B$ ). Irradiated EDDS (free ligand, not chelated with $\mathrm{Fe})\left(179 \mu \mathrm{mol} \cdot \mathrm{L}^{-1}\right)$ was affected by irradiation. Irradiated EDDS absorbance increased over time with SAU for T $=0,6$, and $12 \mathrm{~h}$ irradiation of 19.82, 22.02, and 28.36, respectively (Fig. 7). The absorbance spectra for free ligand EDDS in Figures 5 and 7 are different. This is the result of EDDS concentration: $17.9 \mathrm{mmol} \cdot \mathrm{L}^{-1}$ (Fig. 5) versus 179 $\mu \mathrm{mol} \cdot \mathrm{L}^{-1}$ (Fig. 7). No change in absorbance spectra was observed for nonirradiated EDDS, 


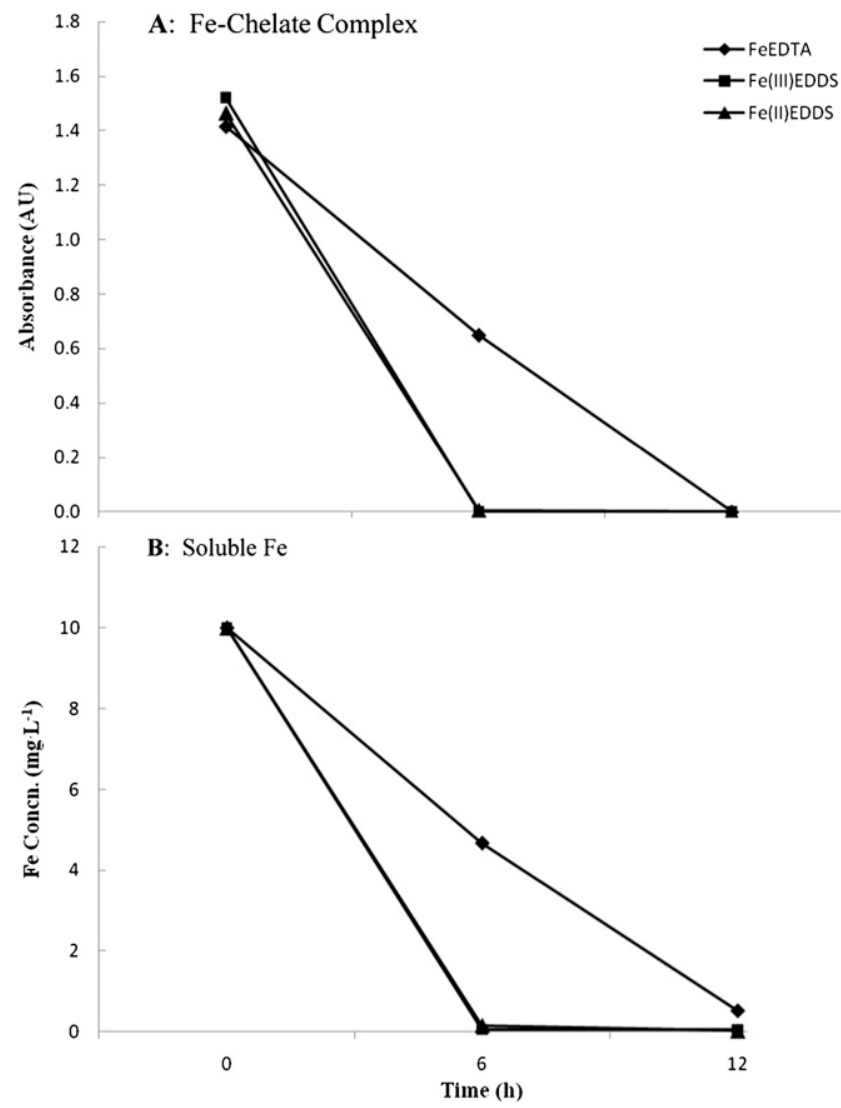

Fig. 6. Photodegradation of FeEDDS and FeEDTA: (A) FeEDTA and FeEDDS [Fe(II)EDDS and $\mathrm{Fe}(\mathrm{III}) \mathrm{EDDS}$ ] determined spectrophotometrically at 258 and $238 \mathrm{~nm}$, respectively; and (B) $\mathrm{Fe}$ determined by inductively coupled plasma for $179 \mu \mathrm{mol} \cdot \mathrm{L}^{-1} \mathrm{Fe}$-chelate solutions. Blanks used for determining absorbance (A) for FeEDDS and FeEDTA chelates were [S, $\mathrm{S}^{\prime}$ ]-EDDS (free ligand) and distilled-deionized water, respectively. Solutions were irradiated with a HID light source providing $2772 \mu \mathrm{mol} \cdot \mathrm{m}^{-2} \cdot \mathrm{s}^{-1}$ (200 to $800 \mathrm{~nm}$ ) measured at the surface of 1-L low-density polyethylene containers. Scans are the mean of four replications.

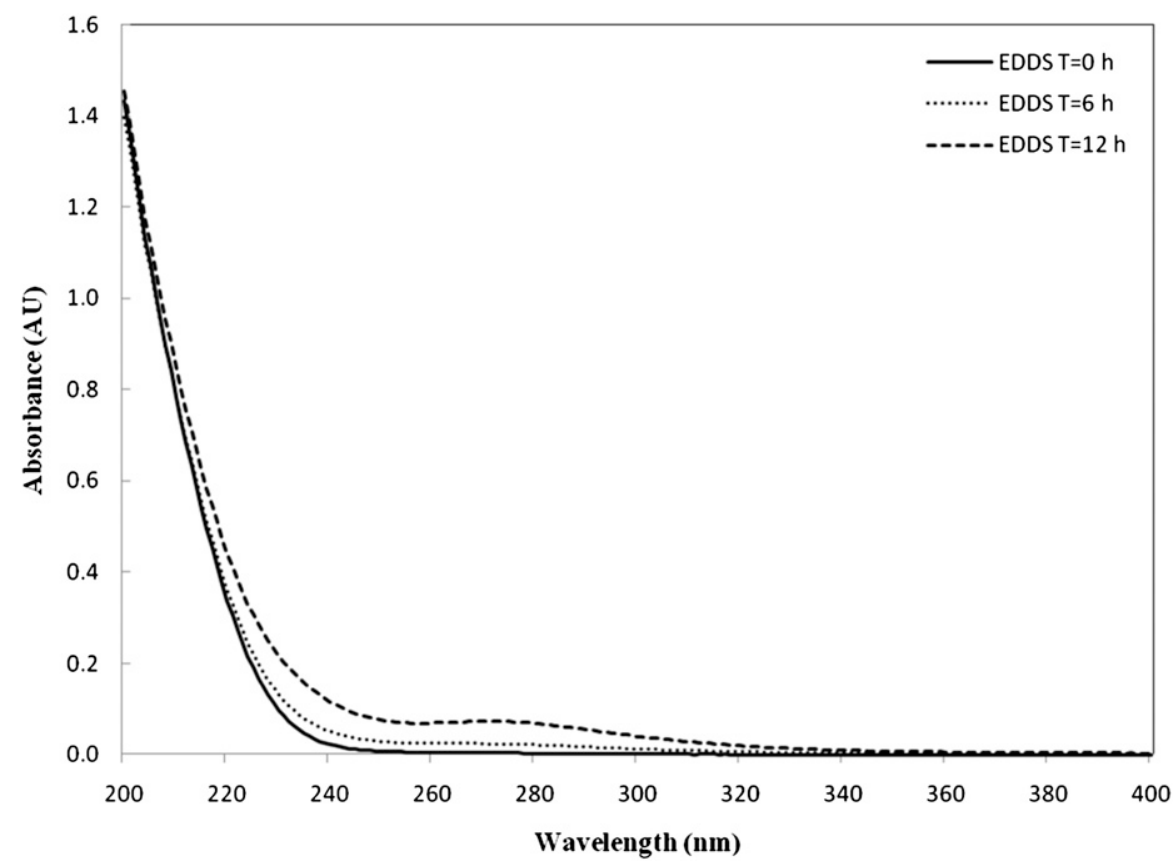

Fig. 7. Absorbance spectra of $\left[\mathrm{S}, \mathrm{S}^{\prime}\right]$-EDDS complexone $\left(179 \mu \mathrm{mol} \cdot \mathrm{L}^{-1}\right)$ irradiated with a HID light source providing $2772 \mu \mathrm{mol} \cdot \mathrm{m}^{-2} \cdot \mathrm{s}^{-1}$ (200 to $800 \mathrm{~nm}$ ) measured at the surface of $1-\mathrm{L}$ low-density polyethylene containers. Scans are the mean of four replications $(n=4)$ at time $(\mathrm{T}) 0(-), 6(\cdots)$, and $12(--)$ h.
FeEDDS, and FeEDTA solutions over the course of the study (data not shown). These data are consistent with work by Metsärinne et al. (2001) who found that FeEDDS photodegraded more rapidly than FeEDTA. Differences between the cited work (Metsärinne et al., 2001) and the current study include: 1) in the cited work, an isomeric mixture of EDDS containing $25 \%\left[\mathrm{~S}, \mathrm{~S}^{\prime}\right], 25 \%\left[\mathrm{R}, \mathrm{R}^{\prime}\right]$, and $50 \%$ $\left[S, R^{\prime} / R, S^{\prime}\right]$ was used, whereas in the current study, a $100 \%$ [S, $\left.\mathrm{S}^{\prime}\right]$-EDDS solution was used for photochemistry; and 2) in the cited work, loss of the Fe-chelate complex was measured only by absorbance whereas in the current study, loss of soluble Fe was directly measured (by ICP-OES) in addition to loss of the Fechelate complex by absorbance. Previous work by the author showed that FeEDTA degrades faster than FeDTPA when irradiated (Albano and Miller, 2001a). Therefore, vulnerability to photodegradation would follow the profile: FeEDDS $>$ FeEDTA $>$ FeDTPA.

\section{Conclusions}

Results of this study demonstrated that FeEDDS performance as a fertilizer Fe source is comparable to that of FeEDTA or FeDTPA in the production of marigold with no significant differences in $\mathrm{Fe}$ or $\mathrm{Mn}$ nutrition or plant growth as represented by total leaf DW. IronEDDS, however, is more vulnerable to photodegradation than either FeEDTA or FeDTPA when exposed to light, meaning that fertilizer stock solutions formulated with FeEDDS will need to be protected from light to prevent the rapid photolysis of the Fe-chelate complex. Even the free EDDS complexone's absorbance shifted when exposed to light indicating that EDDS solutions will also need to be protected from illumination. The fundamental difference between EDDS and EDTA or DTPA for purposes as a fertilizer component appears to be that $\left[\mathrm{S}, \mathrm{S}^{\prime}\right]$-EDDS readily biodegrades. This difference has water-quality implications because the persistence of EDDS in the environment is reported to be less than that of EDTA or DTPA. In other words, offsite discharge of EDDS may pose a lower risk for (re)solubilizing sediment-bound heavy metals and subsequently transporting them into the water column where degradation to irrigation, environmental, and/or drinking water resources may result.

\section{Literature Cited}

Albano, J.P. and W.B. Miller. 2001a. Photodegradation of FeDTPA in nutrient solutions. I. Effects of irradiance, wavelength, and temperature. HortScience 36:313-316.

Albano, J.P. and W.B. Miller. 2001b. Photodegradation of FeDTPA in nutrient solutions. II. Effects on root physiology and foliar $\mathrm{Fe}$ and $\mathrm{Mn}$ levels in marigold. HortScience 36:317-320.

Albano, J.P. and W.B. Miller. 2003. Ferric ethylenediamine-tetraacetic acid photodegradation in a commercially produced soluble fertilizer affects iron uptake in tomato. HortTechnology 13:289-292.

Bucheli-Witschel, M. and T. Egli. 2001. Environmental fate and microbial degradation of aminopolycarboxylic acids. Federation of European Microbial Societies. Microbiol. Rev. 25:69-106. 
Egli, T. 2001. Biodegradation of metal-complexing aminopolycarboxylic acids. J. Biosci. Bioeng. 92:89-97.

Gorokhovatskaya, M.Ya., N.N. Tananaeva, E.K Trunova, and N.A. Kostromia. 1990. Complex formation in the system $\mathrm{Fe}$ (III)-ethylenediamine disuccinic acid. Theor. Exp. Chem. 26:180 184.

Grundler, O.J., A.T.M. van der Steen, and J. Wilmot. 2005. Overview of European risk assessment on EDTA, p. 336-347. In: Nowack, B. and J.M. VanBriesen (eds.). Bigeochemistry of chelating agents. Oxford University Press. American Chemical Society, symposium series 910. ISBN: 0-8412-3897-9.

Jones, P.W. and D.R. Williams. 2001. Chemical speciation used to assess [S, $\left.\mathrm{S}^{\prime}\right]$-ethylenediaminedisuccinic acid (EDDS) as a readily-biodegradable replacement for EDTA in radiochemical decontamination formations. Appl. Radiat. Isot. 54:587-593.

Metsärinne, S., T. Tuhkanen, and R. Aksela. 2001. Photodegradation of ethylenediaminetetracetic acid (EDTA) and ethylenediamine disuccinic acid (EDDS) with natural UV radiation range. Chemosphere 45:949-955.

Nelson, P.V. 1999. Nutrition. In: Buck, C.A., S.A. Carver, M.L. Gaston, P.S. Konjoian, L.A. Kunkle, and M.F. Wilt (eds.). Tips on growing bedding plants. Ohio Florist' Association Services, Inc., Columbus, $\mathrm{OH}$.

Nörtemann, B. 2005. Biodegradation of chelating agents: EDTA, DTPA, PDTA, NTA, and EDDS, p. 150-170. In: Norwack, B. and J.M. VanBriesen (eds.). Bigeochemistry of chelating agents. Oxford University Press. American Chemical Society, symposium series 910. ISBN: 0-8412-3897-9.

Norwack, B. and J.M. VanBriesen. 2005. Chelating agents in the environment, p. 1-18. In: Norwack, B. and J.M. VanBriesen (eds.). Bigeochemistry of chelating agents. Oxford University Press. American Chemical Society, symposium series 910. ISBN: 0-8412-3897-9.

Orama, M., H. Hyvönen, H. Saarinen, and R. Aksela. 2002. Complexation of $[S, S]$ and mixed sterioisomers of $\mathrm{N}, \mathrm{N}^{\prime}$-ethylenediaminedisuccinic acid (EDDS) with $\mathrm{Fe}(\mathrm{III}), \mathrm{Cu}(\mathrm{II})$, $\mathrm{Mn}(\mathrm{II})$ ions in aqueous solution. J. Chem. Soc., Dalton Trans. 24:4639-4643.

Oviedo, C. and J. Rodriguez. 2003. EDTA: The chelating agent under environmental scrutiny. Quim. Nova 26:901-905.

Schmidt, C.K. and H.-J. Brauch. 2004. Impact of aminopolycarboxylates on aquatic organisms and eutrophication: Overview of available data. Environ. Toxicol. 19:620-637.

Schowanek, D., T.C.J. Feijetel, C.M. Perkins, F.A. Hartman, T.W. Federle, and R.J. Larson. 1997.
Biodegradation of $[\mathrm{S}, \mathrm{S}],[\mathrm{R}, \mathrm{R}]$, and mixed stereoisomers of ethylene diamine disuccinic acid (EDDS), a transitional metal chelator. Chemosphere 34:2375-2391.

Tandy, S., A. Ammann, R. Schulin, and B. Nowack. 2006. Biodegradation and speciation of residual SS-ethylenediaminedisuccinic acid (EDDS) in soil solution left after soil washing. Environ. Pollut. 142:191-199.

U.S. EPA Method 3052. 1997. Microwave assisted acid digestion of siliceous and organically based matrices, Test methods for evaluating solid waste, physical/chemical methods. EPA Publ. SW-846, third edition, as amended by updates I, II, III, and IIIB finalized in the Federal Register on 13 June 1997.

U.S. EPA Method 6010B. 1997. Inductively coupled plasma-atomic emission spectrometry, Test methods for evaluating solid waste, physical/ chemical methods. EPA Publ. SW-846, third edition, as amended by updates I, II, III, and IIIB finalized in the Federal Register on 13 June 1997. Vetanovetz, R.P. 1996. Tissue analysis and interpretation, p. 197-219. In: Reed, D.W. (ed.). A grower's guide to water, media, and nutrition for greenhouse crops. Ball Publishing, Batavia, IL.

Yang, W.T. and B. Ranby. 1996. The role of UV radiation in the photografting process. Polym. Bull. 37:89-96. 